\title{
Transfer of [Flexibacter] sancti, [Flexibacter] filiformis, [Flexibacter] japonensis and [Cytophaga] arvensicola to the genus Chitinophaga and description of Chitinophaga skermanii sp. nov.
}

\author{
Peter Kämpfer, ${ }^{1}$ Chiu-Chung Young, ${ }^{2}$ K. R. Sridhar, ${ }^{3}$ A. B. Arun, ${ }^{2}$ \\ Wei An Lai, ${ }^{2}$ Fo Ting Shen ${ }^{2}$ and P. D. Rekha ${ }^{2}$ \\ ${ }^{1}$ Institut für Angewandte Mikrobiologie, Universität Giessen, IFZ - Heinrich-Buff-Ring 26-32, \\ D-35392 Giessen, Germany \\ ${ }^{2}$ College of Agriculture and Natural Resources, Department of Soil and Environmental \\ Sciences, National Chung Hsing University, Taichung, 402, Taiwan, ROC \\ ${ }^{3}$ Department of Biosciences, Mangalore University, Mangalagangotri, India
}

Correspondence

Peter Kämpfer

peter.kaempfer@agrar.unigiessen.de
The monospecific genus Chitinophaga was originally proposed by Sangkhobol \& Skerman (1981) to include strains of filamentous, chitinolytic, gliding bacteria that transform on ageing into spherical bodies. These bodies were first likened to the microcycst of Sporocytophaga myxococcoides (Leadbetter, 1989), but Reichenbach (1992) disputed the formation of microcysts by Chitinophaga pinensis and pointed to the similarities between the morphology of Chitinophaga pinensis and [Flexibacter] filiformis. Sly et al. (1999) compared the 16S rRNA gene sequences of Chitinophaga pinensis and [Flexibacter] filiformis and found that these two chitinolytic bacteria formed a separate lineage that also included [Flexibacter] sancti, [Cytophaga] arvensicola and [Flavobacterium] ferrugineum, which had already been shown by Nakagawa \& Yamasato (1993). Later, Nakagawa et al. (2002) showed that [Flexibacter] japonensis also grouped into this lineage. These authors have previously suggested that [Flexibacter] filiformis, [Flexibacter] sancti and [Cytophaga] arvensicola may constitute a distinct genus on the basis of their

The GenBank/EMBL/DDBJ accession number for the 16S rRNA gene sequence of strain CC-SG1B ${ }^{\top}$ is AJ971483. phylogenetic relationship as determined from 16S rRNA gene sequence similarities, their strict respiratory metabolism, MK-7 menaquinone content and a base composition in the range $42 \cdot 8-48 \cdot 6 \mathrm{~mol} \% \mathrm{G}+\mathrm{C}$.

It was also shown by Takeuchi \& Yokota (1992) that [Flavobacterium] ferrugineum was closely related to this group. Recently, Xie \& Yokota (2006) proposed the new genus Terrimonas to accommodate [Flavobacterium] ferrigineum and added a second species to this genus, Terrimonas lutea.

Here, we present the characterization of a novel representative of this lineage and propose the formal reclassification of these organisms into the genus Chitinophaga.

A yellow-coloured strain, CC-SG1B ${ }^{\mathrm{T}}$, was isolated from faeces of the millipede Arthrosphaera magna collected in India. Subcultivation was done on nutrient agar (Oxoid) at $28^{\circ} \mathrm{C}$ for $24 \mathrm{~h}$. On this agar, CC-SG1B ${ }^{\mathrm{T}}$ was able to grow at $10-36^{\circ} \mathrm{C}$, but not at 4 or $45^{\circ} \mathrm{C}$. Growth at $30^{\circ} \mathrm{C}$ was also observed on TSA and R2A agar, but not on SS agar (Salmonella-Shigella agar) or MacConkey agar (all from Oxoid). The $\mathrm{pH}$ range ( $\mathrm{pH} 4-10$ at intervals of 1 ) and 
requirement for $0,1,2,3,5$ and $7 \% \mathrm{NaCl}(\mathrm{w} / \mathrm{v})$ was determined using R2A medium. Gram-staining was performed as described by Gerhardt et al. (1994). Cell morphology was observed under a Zeiss light microscope at $\times 1000$, using cells that had been grown for $24 \mathrm{~h}$ at $28^{\circ} \mathrm{C}$ on nutrient agar (Oxoid). Oxidase activity was tested using oxidase reagent (bioMérieux) according to the instructions of the manufacturer. Flexirubin-like pigments were observed by flooding the plates with $20 \%(\mathrm{w} / \mathrm{v})$ potassium hydroxide (Fautz \& Reichenbach, 1980).

The cells were Gram-negative, rod-shaped, non-sporeforming, non-fluorescent and oxidase-positive. Results on the cell morphology and other details are given in the species description.

The 16S rRNA gene was analysed as described previously (Kämpfer et al., 2003; Young et al., 2005). Analysis of the sequence data was performed by using the software package MEGA version 2.1 (Kumar et al., 2001), after multiple alignment of sequences by CLUSTAL X (Thompson et al., 1997). A distance matrix method (distance options according to the Kimura two-parameter model) using clustering with the neighbour-joining method (Fig. 1) as well as a discrete character-based maximum-parsimony method (data not shown) were performed. In each case, bootstrap values were calculated based on 1000 replications. The 16S rRNA gene sequence of strain CC-SG1B ${ }^{\mathrm{T}}$ was a continuous stretch of $1384 \mathrm{bp}$. Sequence similarity calculations indicated that strain CC-SG1B ${ }^{\mathrm{T}}$ showed the highest degree of similarity to [Flexibacter] filiformis ATCC $29495^{\mathrm{T}}$ $(94 \cdot 8 \%)$ and [Flexibacter] japonensis IFO $16041^{\mathrm{T}}(94 \cdot 6 \%)$, which was described by Fujita et al. (1996). The similarity to Chitinophaga pinensis ACM $2034^{\mathrm{T}}$ was $93 \cdot 3 \%$. Lower sequence similarities $(<94.5 \%)$ were found with all other species of this lineage.

The determination of DNA G $+\mathrm{C}$ contents was performed by the methods outlined by Mesbah et al. (1989) using a reversed-phase column (Supelco LC-18-S; Supelco). The $\mathrm{G}+\mathrm{C}$ content of strain $\mathrm{CC}-\mathrm{SG} 1 \mathrm{~B}^{\mathrm{T}}$ was $40 \cdot 7 \mathrm{~mol} \%$.
Chemotaxonomic analyses of respiratory quinones (according to Altenburger et al., 1996) and fatty acids (according to Kämpfer \& Kroppenstedt, 1996) were performed. Although respiratory quinones have low resolution within this group, the presence of MK-7 supports affiliation of strain CC$\mathrm{SG}_{\mathrm{B}} \mathrm{B}^{\mathrm{T}}$ to this group, where all species investigated to date have MK-7 as the major quinone.

The fatty acid profile of strain $\mathrm{CC}-\mathrm{SG}_{1 \mathrm{~B}}{ }^{\mathrm{T}}$ revealed 15:0 iso and $16: 1 \omega 5 c$ as the major fatty acids and $17: 0$ iso $3-\mathrm{OH}$ and 15:0 iso $3-\mathrm{OH}$ as the major hydroxy fatty acids. This is in essential agreement with the fatty acid patterns of [Flexibacter] sancti, [Flexibacter] filiformis, [Flexibacter] japonenis and Chitinophaga pinensis. The two Terrimonas species showed large amounts of $15: 1$ iso $\mathrm{H}$ instead of $16: 1 \omega 5 c$ (Table 1), and thus could be clearly differentiated from [Flexibacter] sancti, [Flexibacter] filiformis, [Flexibacter] japonenis, Chitinophaga pinensis and strain CC-SG1B ${ }^{\mathrm{T}}$.

Results of the physiological characterization of CC-SG1B ${ }^{\mathrm{T}}$ are given in the species description, using methods that were described previously (Kämpfer et al., 1991). Additional biochemical tests were performed to assess the carbon source utilization pattern by using Biolog GN2 plates, whilst hydrolysis of 19 substrates was investigated using the API ZYM system and API 20E according to the methods outlined by the manufacturer (bioMérieux). Hydrolysis of chitin was studied by the methods of Smibert \& Krieg (1994). The results are given in the species description. Strain CC-SG1B ${ }^{\mathrm{T}}$ was able to utilize many carbohydrates, but organic acids and amino acids were not utilized.

Despite the relatively low 16S rRNA gene sequence similarities of these organisms $(88 \cdot 5-96 \cdot 4 \%)$, all the strains under study show a remarkable congruence in phenotypic characters. They all produce MK-7 as the major menaquinone and have homospermidine as the predominant polyamine (Hamana \& Nakagawa, 2001). The fatty acid profiles were very similar, composed mainly of $15: 0$ iso and $16: 1 \omega 5 c$ as the major fatty acids and $17: 0$ iso $3-\mathrm{OH}$ and $15: 0$ iso $3-\mathrm{OH}$ as the major hydroxy fatty acids (Table 1 ).

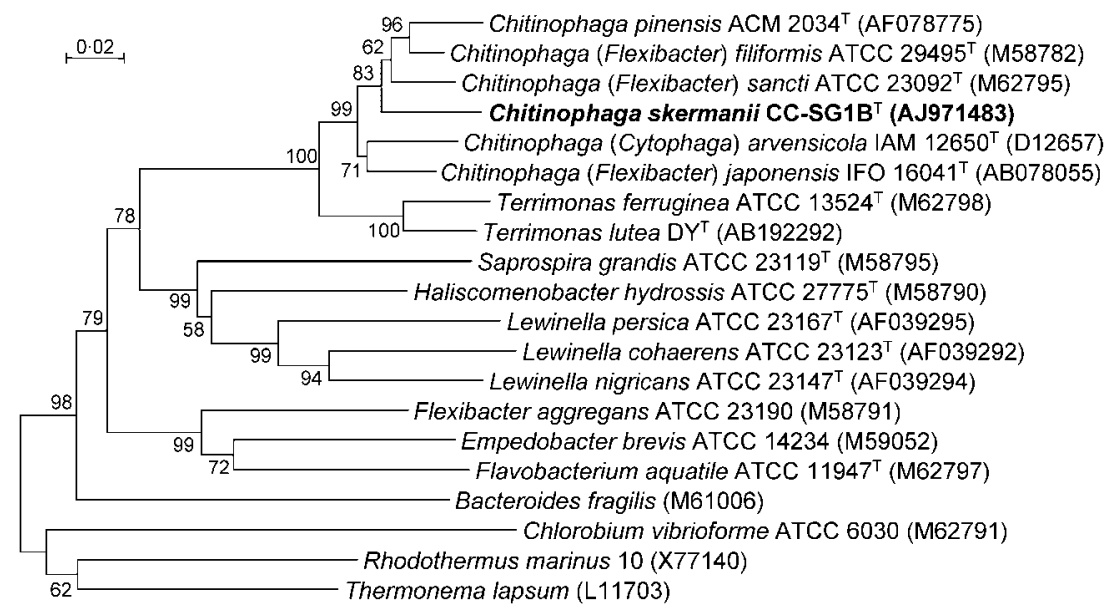

Fig. 1. Phylogenetic analysis based on $16 \mathrm{~S}$ rRNA gene sequences available from the EMBL database (accession numbers in parentheses) constructed after multiple alignment of data by CLUSTAL X (Thompson et al., 1997). Distances were calculated (distance options according to the Kimura-2 model) and clustering with the neighbour-joining method was performed by using the software package MEGA version 2.1 (Kumar et al., 2001). Bootstrap values based on 1000 replications are listed as percentages at branching points. Bar, 0.02 nucleotide substitutions per nucleotide position. 
Table 1. Fatty acid profiles of Chitinophaga and Terrimonas species

Strains: 1, Chitinophaga pinensis DSM $2588^{\mathrm{T}}$; 2, Chitinophaga skermanii sp. nov. CC-SG1B ${ }^{\mathrm{T}}$; 3, Chitinophaga (Cytophaga) arvensicola DSM $3695^{\mathrm{T}}$; 4, Chitinophaga (Flexibacter) japonensis DSM $13484^{\mathrm{T}}$; 5, Chitinophaga (Flexibacter) sancti DSM $784^{\mathrm{T}} ; 6$, Chitinophaga (Flexibacter) filiformis CCUG $12809^{\mathrm{T}}$; 7, Terrimonas ferruginea IAM $15098^{\mathrm{T}} ; 8$, Terrimonas lutea $\mathrm{DY}^{\mathrm{T}}$. Data for T. ferruginea and T. lutea were taken from Xie \& Yokota (2006) (confirmed in this study). Values are percentages of total fatty acids.

\begin{tabular}{|c|c|c|c|c|c|c|c|c|}
\hline Fatty acid & 1 & 2 & 3 & 4 & 5 & 6 & 7 & 8 \\
\hline Unknown $13 \cdot 565$ & $2 \cdot 6$ & $4 \cdot 4$ & $3 \cdot 6$ & $3 \cdot 1$ & $3 \cdot 2$ & $2 \cdot 5$ & $1 \cdot 3$ & $3 \cdot 2$ \\
\hline $13: 0$ iso & & & & & & & $0 \cdot 5$ & $0 \cdot 5$ \\
\hline $13: 0$ & & & & & & & $0 \cdot 2$ & $0 \cdot 7$ \\
\hline $14: 0$ iso & & & & & & & $1 \cdot 1$ & $4 \cdot 3$ \\
\hline $14: 0$ & $0 \cdot 7$ & $1 \cdot 8$ & $1 \cdot 4$ & $0 \cdot 5$ & $0 \cdot 7$ & $0 \cdot 9$ & $0 \cdot 5$ & $0 \cdot 4$ \\
\hline $15: 02-\mathrm{OH}$ & & & $0 \cdot 3$ & & & & $0 \cdot 8$ & $0 \cdot 3$ \\
\hline $15: 03-\mathrm{OH}$ & & & & & & & $0 \cdot 3$ & \\
\hline $15: 0$ iso $3-\mathrm{OH}$ & $3 \cdot 1$ & $2 \cdot 6$ & $3 \cdot 0$ & $2 \cdot 4$ & $3 \cdot 4$ & $3 \cdot 3$ & $2 \cdot 2$ & $2 \cdot 3$ \\
\hline $15: 0$ iso & $30 \cdot 4$ & $47 \cdot 3$ & $35 \cdot 3$ & $40 \cdot 0$ & $44 \cdot 0$ & $37 \cdot 3$ & $28 \cdot 4$ & $34 \cdot 8$ \\
\hline $15: 0$ anteiso & & & $0 \cdot 6$ & $0 \cdot 5$ & & & $0 \cdot 6$ & \\
\hline $15: 1$ iso & & & & & & & $26 \cdot 2$ & $21 \cdot 8$ \\
\hline Unknown $11 \cdot 543$ & & $0 \cdot 8$ & $0 \cdot 5$ & & & & & \\
\hline $15: 0$ & $0 \cdot 4$ & $0 \cdot 4$ & $0 \cdot 4$ & & & & $2 \cdot 7$ & $0 \cdot 4$ \\
\hline Unknown 14.959 & $0 \cdot 3$ & $0 \cdot 4$ & $0 \cdot 3$ & & & & & \\
\hline Summed feature $2^{*}$ & & $0 \cdot 4$ & $0 \cdot 4$ & $0 \cdot 5$ & & & & \\
\hline iso $17: 1 \omega 9 c$ & & & $0 \cdot 3$ & & $1 \cdot 1$ & & & \\
\hline Summed feature 3 & $7 \cdot 7$ & $3 \cdot 5$ & $3 \cdot 7$ & $3 \cdot 3$ & $16 \cdot 0$ & $11 \cdot 2$ & $11 \cdot 2$ & $14 \cdot 9$ \\
\hline Summed feature 4 & & $0 \cdot 4$ & & $1 \cdot 3$ & $0 \cdot 8$ & & & \\
\hline 16:0 10-methyl & & & $0 \cdot 4$ & $0 \cdot 9$ & & & & \\
\hline $16: 1 \omega 11 c$ & $1 \cdot 9$ & $0 \cdot 4$ & $0 \cdot 5$ & $1 \cdot 0$ & $0 \cdot 9$ & & & \\
\hline $16: 1 \omega 5 c$ & $33 \cdot 2$ & $24 \cdot 4$ & $33 \cdot 6$ & $22 \cdot 2$ & $13 \cdot 5$ & $25 \cdot 5$ & & \\
\hline $16: 02-\mathrm{OH}$ & $0 \cdot 7$ & & & $3 \cdot 0$ & $0 \cdot 7$ & $1 \cdot 1$ & & \\
\hline $16: 0$ & $4 \cdot 2$ & $3 \cdot 5$ & $5 \cdot 1$ & $3 \cdot 0$ & $4 \cdot 2$ & $4 \cdot 3$ & $1 \cdot 7$ & $1 \cdot 1$ \\
\hline $16: 0$ iso & & & $0 \cdot 3$ & & & & $1 \cdot 4$ & \\
\hline $16: 0$ iso $3-\mathrm{OH}$ & $0 \cdot 4$ & $0 \cdot 4$ & $0 \cdot 5$ & $0 \cdot 4$ & & & $0 \cdot 7$ & \\
\hline $16: 03-\mathrm{OH}$ & $1 \cdot 2$ & $1 \cdot 6$ & $1 \cdot 7$ & $0 \cdot 8$ & $0 \cdot 5$ & $1 \cdot 2$ & $2 \cdot 5$ & $3 \cdot 3$ \\
\hline $17: 0$ anteiso & & & & $0 \cdot 4$ & & & & \\
\hline $17: 02-\mathrm{OH}$ & & & $0 \cdot 4$ & $0 \cdot 4$ & & & & \\
\hline $17: 0$ iso & $0 \cdot 4$ & $0 \cdot 6$ & $0 \cdot 4$ & $1 \cdot 8$ & $0 \cdot 6$ & & & \\
\hline Unknown $16 \cdot 582$ & $1 \cdot 1$ & $0 \cdot 7$ & $0 \cdot 8$ & $1 \cdot 1$ & $1 \cdot 3$ & $0 \cdot 9$ & $1 \cdot 3$ & $1 \cdot 8$ \\
\hline $17: 0$ iso $3-\mathrm{OH}$ & $11 \cdot 5$ & $5 \cdot 0$ & $5 \cdot 9$ & $13 \cdot 0$ & $9 \cdot 1$ & $11 \cdot 8$ & $15 \cdot 3$ & $14 \cdot 2$ \\
\hline
\end{tabular}

* Summed features are groups of two or three fatty acids that could not be separated. Summed feature 2: 12:0 alde/unknown; summed feature 3, $16: 1 \omega 7 c / 15: 0$ iso $2-\mathrm{OH}$; summed feature $4,17: 1$ anteiso $\mathrm{B} / 17: 1$ iso $\mathrm{I}$.

Only a few differences are reported in cell morphology and certain physiological tests (Tables 2 and 3 ).

From $16 \mathrm{~S}$ rRNA gene sequencing studies, it is obvious that organisms of this lineage do not belong to the genus Flexibacter sensu stricto with the type species Flexibacter flexilis (Nakagawa et al., 2002; Sly et al., 1999) or to the genus Cytophaga sensu stricto with the type species Cytophaga hutchinsonii (Nakagawa et al., 2002; Sly et al., 1999). It should be noted here that species of the phylogenetically related genus Lewinella share only $84 \cdot 7-88 \cdot 4 \%$ 16S rRNA gene sequence similarity.

For all these reasons, it is proposed to reclassify [Flexibacter] sancti, [Flexibacter] filiformis, [Flexibacter] japonenis and [Cytophaga] arvensicola to the genus Chitinophaga as the new combinations Chitinophaga sancti comb. nov., Chitinophaga filiformis comb. nov., Chitinophaga japonensis comb. nov. and Chitinophaga arvensicola comb. nov. A novel species, Chitinophaga skermanii sp. nov., is described to accommodate strain CC-SG1B ${ }^{\mathrm{T}}$.

\section{Emended description of the genus Chitinophaga Sangkhobol and Skerman}

The description is that of Sangkhobol \& Skerman (1981) with the following modifications. A resting stage may be formed. Motility by gliding is possessed by some, but not all species. Some species hydrolyse chitin and some hydrolyse cellobiose.

\section{Description of Chitinophaga sancti comb. nov.}

Chitinophaga sancti [sanc'ti. L. n. sanctus saint; L. gen. n. sancti of Saint, perhaps named in honour of Dr Santos Soriano, from whose laboratory the type strain was supplied (the etymology is not clear)].

Basonym: Flexibacter sancti Lewin 1969, 199 ${ }^{\mathrm{AL}}$.

The description is identical to that given by Lewin (1969) with the additional chemotaxonomic data provided by Reichenbach (1989), Hamana \& Nakagawa (2001) and this study. The type strain is ATCC $23092^{\mathrm{T}}=\mathrm{DSM} 784^{\mathrm{T}}=$ HAMBI $1988^{\mathrm{T}}=$ NBRC $15057^{\mathrm{T}}=$ LMG $8377^{\mathrm{T}}=$ VKM B- $1428^{\mathrm{T}}$.

\section{Description of Chitinophaga filiformis comb. nov.}

Chitinophaga filiformis (fi.li.for'mis. L. neut. n. filum a thread; L. suff. -formis like, of the shape of; N.L. fem. adj. filiformis thread-shaped).

Basonym: Flexibacter filiformis (ex Solntseva 1940) Reichenbach 1989.

The description is identical to that given by Reichenbach (1989) with the additional chemotaxonomic data provided by Hamana \& Nakagawa (2001) and this study. The type strain is strain Fx e1 Reichenbach ${ }^{\mathrm{T}}=$ ATCC $29495^{\mathrm{T}}=$ CCUG $12809^{\mathrm{T}}=\mathrm{CIP} \quad 106401^{\mathrm{T}}=\mathrm{DSM} \quad 527^{\mathrm{T}}=$ HAMBI $\quad 1966^{\mathrm{T}}=$ NBRC $15056^{\mathrm{T}}$.

\section{Description of Chitinophaga japonensis comb. nov.}

Chitinophaga japonensis (ja.po.nen'sis. N.L. fem. adj. japonensis pertaining to Japan). 
Table 2. Phenotypic characteristics of Chitinophaga and Terrimonas species

Strains: 1, Chitinophaga pinensis ACM $2034^{\mathrm{T}} ; 2$, Chitinophaga skermanii sp. nov. CC-SG1B ${ }^{\mathrm{T}} ; 3$, Chitinophaga (Cytophaga) arvensicola IAM $12650^{\mathrm{T}} ; 4$, Chitinophaga (Flexibacter) japonensis NBRC $16041^{\mathrm{T}} ; 5$, Chitinophaga (Flexibacter) sancti NBRC $15057^{\mathrm{T}}$; 6 , Chitinophaga (Flexibacter) filiformis NBRC $150656^{\mathrm{T}} ; 7$, Terrimonas ferruginea IAM $15098^{\mathrm{T}} ; 8$, Terrimonas lutea IAM $15284^{\mathrm{T}}$. All the strains were isolated from soil and produce acid from glucose; $\mathrm{H}_{2} \mathrm{~S}$ production is absent from all strains. Major hydroxylated fatty acids in all strains are $17: 0$ iso 3-OH and 15:0 iso 3-OH. Data for reference strains were taken from Xie \& Yokota (2006), Takeuchi \& Yokota (1992), Oyaizu et al. (1982), Bernardet et al. (1996) and Fujita et al. (1996). ND, No data available; HSpd, homospermidine.

\begin{tabular}{|c|c|c|c|c|c|c|c|c|}
\hline Characteristic & 1 & 2 & 3 & 4 & 5 & 6 & 7 & 8 \\
\hline Pigment & Yellow & Yellow & Yellow-orange & Yellow-orange & Golden yellow & Golden yellow & Yellow & Yellow \\
\hline Cell length $(\mu \mathrm{m})$ & $<40$ & $1-2$ & $0 \cdot 6-4$ & $2-18$ & $2-15$ & $30-80$ & $1-2$ & $1-2$ \\
\hline Filamentous shape & + & - & - & + & + & + & - & - \\
\hline Quinone system & MK-7 & MK-7 & MK-7 & MK-7 & ND & ND & MK-7 & MK-7 \\
\hline Oxidase & + & + & + & + & ND & + & + & + \\
\hline Catalase & + & + & + & + & - & - & + & + \\
\hline Urease & + & - & - & $\mathrm{ND}$ & ND & $\mathrm{ND}$ & - & - \\
\hline Gelatin liquefaction & + & + & - & + & + & + & + & + \\
\hline Chitin degradation & + & ND & - & - & - & + & - & - \\
\hline
\end{tabular}

${ }^{\star}$ In addition to 15:0 iso, which is a major component in all strains. 14:0 iso is found only in Terrabacter species (in minor amounts), and not in Chitinophaga species.

Basonym: Flexibacter japonensis Fujita et al. 1997.

The description is identical to that given by Fujita et al. (1996) and Reichenbach (1989) with the additional chemotaxonomic data provided by Hamana \& Nakagawa (2001) and this study. The type strain is strain $758^{\mathrm{T}}=\mathrm{CIP}$ $105790^{\mathrm{T}}=\mathrm{DSM} 13484^{\mathrm{T}}=$ NBRC $16041^{\mathrm{T}}=\mathrm{JCM} 9735^{\mathrm{T}}$.

\section{Description of Chitinophaga arvensicola comb. nov.}

Chitinophaga arvensicola [ar.ven'si.co'la. L. adj. arvensis belonging to or living in the fields; L. suff. -cola from L. n. incola inhabitant; N.L. n. arvensicola (nominative in apposition) an inhabitant of the fields].

Basonym: Cytophaga arvensicola Oyaizu et al. 1983.

The description is identical to that given by Oyaizu et al. (1982) and Reichenbach (1989) with the additional chemotaxonomic data provided by Hamana \& Nakagawa (2001) and this study. The type strain is strain $\mathrm{M} 64^{\mathrm{T}}=$ ATCC $51264^{\mathrm{T}}=\mathrm{CIP} 104804^{\mathrm{T}}=\mathrm{DSM} 3695^{\mathrm{T}}=\mathrm{IAM}$ $12650^{\mathrm{T}}=$ NBRC $14973^{\mathrm{T}}=\mathrm{JCM} 2836^{\mathrm{T}}$.

\section{Description of Chitinophaga skermanii sp. nov.}

Chitinophaga skermanii (sker.ma' ni.i. N.L. gen. n. skermanii of Skerman, in honour of V. B. D. Skerman, an Australian microbiologist, in recognition of his numerous contributions to the taxonomy of micro-organisms).

Cells are Gram-negative, non-motile, non-spore-forming rods. Aerobic and oxidase-positive. Good growth after $48 \mathrm{~h}$ on nutrient agar, tryptic soy agar and MacConkey agar at 30-40 ${ }^{\circ}$ C. Colonies on nutrient agar are smooth, orange, circular, translucent and shiny with entire edges, becoming mucoid. Orange pigmentation is non-diffusible, nonfluorescent and turns to cherry red upon the addition of $20 \% \mathrm{KOH}$ and retains original colour on addition of $\mathrm{HCl}$. Strains are unable to grow at 5 or $42{ }^{\circ} \mathrm{C}$. Growth occurs at pH 5.5-10 and in $7 \%(\mathrm{w} / \mathrm{v}) \mathrm{NaCl}$. The detailed fatty acid profile is given in Table 1. Positive for $\beta$-galactosidase, acetoin production, gelatinase and oxidation of glucose, mannitol and melibiose and negative for arginine dihydrolase, lysine decarboxylase, citrate utilization, $\mathrm{H}_{2} \mathrm{~S}$ production, urease, tryptophan deaminase, indole production, oxidation of inositol, sorbitol, rhamnose, sucrose, amygdalin and arabinose and cytochrome oxidase activity. Some differentiating tests are given in Table 3 (methods according to Kämpfer et al., 1991). In addition, the following compounds were utilized as sole carbon sources (tested with the Biolog GN system): $\alpha$-cyclodextrin, dextrin, Tweens 40 and 80, $N$-acetyl-D-galactosamine, $N$-acetyl-Dglucosamine, cellobiose, L-fucose, gentiobiose, $\alpha$-D-glucose, $\alpha$-D-lactose, lactulose, maltose, D-mannose, D-melibiose, methyl $\beta$-D-glucoside, D-raffinose, sucrose, D-trehalose, 
Table 3. Differentiating characters of Chitinophaga and Terrimonas species

Strains: 1, Chitinophaga pinensis DSM $2588^{\mathrm{T}} ; 2$, Chitinophaga skermanii CC-SG1B ${ }^{\mathrm{T}}$; 3, Chitinophaga (Cytophaga) arvensicola DSM $3695^{\mathrm{T}}$; 4, Chitinophaga (Flexibacter) japonensis DSM 13484 ${ }^{\mathrm{T}}$; 5, Chitinophaga (Flexibacter) sancti DSM $784^{\mathrm{T}} ; 6$, Chitinophaga (Flexibacter) filiformis CCUG $12809^{\mathrm{T}} ; 7$, Terrimonas ferruginea IAM $15098^{\mathrm{T}} ; 8$, Terrimonas lutea $\mathrm{DY}^{\mathrm{T}}$. Data for T. ferruginea and T. lutea were taken from Xie \& Yokota (2006) unless indicated. Assimilation tests were read after $48 \mathrm{~h}$ of incubation and hydrolysis of chromogenic substrates after $24 \mathrm{~h}$ unless indicated. $o \mathrm{NP}$, $o$-Nitrophenyl; $p \mathrm{NP}, p$-nitrophenyl; $p \mathrm{NA}, p$-nitroanilide.

\begin{tabular}{|c|c|c|c|c|c|c|c|c|}
\hline Test & 1 & 2 & 3 & 4 & 5 & 6 & 7 & 8 \\
\hline \multicolumn{9}{|l|}{ Hydrolysis of: } \\
\hline$o \mathrm{NP} \beta$-D-galactopyranoside & + & + & + & + & + & + & + & - \\
\hline$p \mathrm{NP} \beta$-D-glucopyranoside & + & + & + & + & + & + & - & + \\
\hline pNP phenylphosphonate & + & $+\dagger$ & + & + & + & + & $+^{*}$ & $-{ }^{*}$ \\
\hline pNP phosphorylcholine & + & + & + & + & + & + & $-{ }^{*}$ & $+^{*}$ \\
\hline $\begin{array}{l}\text { 2-Deoxythymidine- } 5^{\prime}-p \mathrm{NP} \\
\text { phosphate }\end{array}$ & + & + & + & + & + & + & $-{ }^{*}$ & $-*$ \\
\hline $\begin{array}{l}\text { L-Glutamate- } \gamma \text {-3-carboxy } \\
\text { pNA }\end{array}$ & $+\dagger$ & $+\ddagger$ & + & $+\dagger$ & + & $+\dagger$ & $-{ }^{*}$ & $-{ }^{*}$ \\
\hline L-Proline $p \mathrm{NA}$ & $+\dagger$ & $+\ddagger$ & + & $+\dagger$ & + & + & $+^{*}$ & $-{ }^{\star}$ \\
\hline \multicolumn{9}{|l|}{ Assimilation of: } \\
\hline$N$-Acetyl-D-glucosamine & + & + & + & + & - & - & - & + \\
\hline L-Arabinose & + & - & $+\dagger$ & + & $+\dagger$ & - & - & + \\
\hline D-Galactose & + & - & - & + & - & - & - & $+^{*}$ \\
\hline Gluconate & - & - & - & - & $+\dagger$ & - & $-*$ & $-*$ \\
\hline D-Mannose & + & + & + & + & - & + & + & + \\
\hline D-Maltose & + & + & + & + & - & + & + & + \\
\hline$\alpha$-D-Melibiose & - & $+\dagger$ & + & + & $+\ddagger$ & $+\dagger$ & - & + \\
\hline L-Rhamnose & $+\dagger$ & - & + & + & - & - & + & - \\
\hline D-Ribose & - & - & + & - & - & - & $-^{*}$ & $-*$ \\
\hline Sucrose & $+\dagger$ & - & $+\dagger$ & + & - & + & - & + \\
\hline Salicin & $+\dagger$ & + & + & + & - & + & $-^{*}$ & $-*$ \\
\hline D-Trehalose & + & $+\ddagger$ & $+\dagger$ & + & - & + & - & + \\
\hline D-Xylose & $+\dagger$ & - & + & + & - & + & + & - \\
\hline Adonitol & - & - & - & + & - & - & $+^{*}$ & $-{ }^{*}$ \\
\hline Maltitol & $+\ddagger$ & - & - & $+\dagger$ & - & $+\dagger$ & $-^{*}$ & $-^{\star}$ \\
\hline
\end{tabular}

${ }^{*}$ Data from this study.

$\nmid$ Positive after 7 days of incubation.

$\ddagger$ Positive after 14 days of incubation.

turanose, monomethyl succinate, acetic acid, D-galacturonic acid, $\alpha$-hydroxybutyric acid, $\alpha$-ketobutyric acid, DL-lactic acid, succinic acid, DL-alanine, L-alanyl glycine, L-asparagine, L-aspartic acid, L-glutamic acid, glycyl L-aspartic acid, glycyl L-glutamic acid, L-proline, L-serine, L-threonine and glycerol. The following carbon sources are not utilized as sole sources of carbon: D-arabitol, propionic acid, citric acid, glycogen, adonitol, L-arabinose, i-erythritol, D-fructose, D-galactose, myo-inositol, D-mannitol, D-psicose, Lrhamnose, D-sorbitol, xylitol, pyruvic acid methyl ester, cis-aconitic acid, formic acid, D-galactonic acid lactone,
D-glucosaminic acid, D-gluconic acid, D-glucuronic acid, $\beta$ and $\gamma$-hydroxybutyric acids, $p$-hydroxyphenylacetic acid, itaconic acid, $\alpha$-ketoglutaric acid, malonic acid, D-saccharic acid, sebacic acid, bromosuccinic acid, quinic acid, succinamic acid, L-pyroglutamic acid, $\alpha$-ketovaleric acid, glucuronamide, L-alaninamide, D-alanine, L-histidine, hydroxy-L-proline, D-serine, L-leucine, L-ornithine, L-phenylalanine, inosine, uridine, thymidine, DL-carnitine, $\gamma$ aminobutyric acid, urocanic acid, phenylethylamine, putrescine, 2-aminoethanol, 2,3-butanediol, DL- $\alpha$-glycerol phosphate, glucose 1-phosphate and glucose 6-phosphate. Positive test results for enzyme activities are seen for alkaline phosphatase, butyrate esterase, caprylate esterase, leucine arylamidase, valine arylamidase, cystine arylamidase, trypsin, acid phosphatase, naphthol-AS-BI-phosphohydrolase, $\alpha$-galactosidase, $\alpha$-glucosidase, $\beta$-glucosidase and $N$-acetyl$\beta$-glucosaminidase; negative test results are observed for myristate esterase, $\alpha$-chymotrypsin, $\beta$-galactosidase, $\beta$ glucuronidase, $\alpha$-mannosidase and $\alpha$-fucosidase.

The type strain is CC-SG1B ${ }^{\mathrm{T}}$ (=CCUG $52510^{\mathrm{T}}=\mathrm{CIP}$ $\left.109140^{\mathrm{T}}\right)$, isolated from faeces of the millipede Arthrosphaera magna.

\section{Acknowledgements}

We thank Mr W. S. Huang for his excellent technical assistance and Dr Jean Euzéby for his advice with the specific epithets and Dr Cheng-Hui Xie and Professor Akira Yokota for providing their manuscript on the description of Terrimonas and the type strains prior to publication. We thank Dr Ashwini Krishnamoorthy for providing the faeces samples of Arthrosphaera magna. We also gratefully acknowledge gifts of strains from Dr Enevold Falsen and Dr Stefan Spring. This research work was kindly supported by a grant from the National Science Council and the Council of Agriculture, Executive Yuan, Taiwan, ROC.

\section{References}

Altenburger, P., Busse, H.-J., Kämpfer, P., Lubitz, W. \& Makristathis, A. (1996). Classification of bacteria isolated from a medieval wall painting. J Biotechnol 47, 39-52.

Bernardet, J.-F., Segers, P., Vancanneyt, M., Berthe, F., Kersters, K. \& Vandamme, P. (1996). Cutting a Gordian knot: emended classification and description of the genus Flavobacterium, emended description of the family Flavobacteriaceae, and proposal of Flavobacterium hydatis nom. nov. (basonym, Cytophaga aquatilis Strohl and Tait 1978). Int J Syst Bacteriol 46, 128-148.

Fautz, E. \& Reichenbach, H. (1980). A simple test for flexirubin-type pigments. FEMS Microbiol Lett 8, 87-91.

Fujita, T., Okamoto, M., Kosako, Y. \& Okuhura, M. (1996). Flexibacter japonensis sp. nov., a new species that produces a novel inhibitor of human leukocyte elastase isolated from soil. Curr Microbiol 33, 89-93.

Gerhardt, P., Murray, R. G. E., Wood, W. A. \& Krieg, N. R. (editors) (1994). Methods for General and Molecular Bacteriology. Washington, DC: American Society for Microbiology.

Hamana, K. \& Nakagawa, Y. (2001). Polyamine distribution profiles in newly validated genera and species within the FlavobacteriumFlexibacter-Cytophaga-Sphingobacterium complex. Microbios 108, $105-118$. 
Kämpfer, P. \& Kroppenstedt, R. M. (1996). Numerical analysis of fatty acid patterns of coryneform bacteria and related taxa. Can J Microbiol 42, 989-1005.

Kämpfer, P., Steiof, M. \& Dott, W. (1991). Microbiological characterisation of a fuel-oil contaminated site including numerical identification of heterotrophic water and soil bacteria. Microb Ecol 21, 227-251.

Kämpfer, P., Dreyer, U., Neef, A., Dott, W. \& Busse, H.-J. (2003). Chryseobacterium defluvii sp. nov., isolated from wastewater. Int J Syst Evol Microbiol 53, 93-97.

Kumar, S., Tamura, K., Jakobsen, I.-B. \& Nei, M. (2001). MEGA2: molecular evolutionary genetics analysis software. Bioinformatics 17, 1244-1245.

Leadbetter, E. R. (1989). Genus IV. Sporocytophaga Stanier 1940, $629^{\mathrm{AL}}$. In Bergey's Manual of Systematic Bacteriology, vol. 3, p. 2061. Edited by J. T. Staley, M. P. Bryant, N. Pfennig \& J. G. Holt. Baltimore: Williams \& Wilkins.

Lewin, R. A. (1969). A classification of flexibacteria. J Gen Microbiol 58, 189-206.

Mesbah, M., Premachandran, U. \& Whitman, W. B. (1989). Precise measurement of the $\mathrm{G}+\mathrm{C}$ content of deoxyribonucleic acid by highperformance liquid chromatography. Int J Syst Bacteriol 39, 159-167.

Nakagawa, Y. \& Yamasato, K. (1993). Phylogenetic diversity of the genus Cytophaga revealed by $16 \mathrm{~S}$ rRNA sequencing and menaquinone analysis. J Gen Microbiol 139, 1155-1161.

Nakagawa, Y., Sakane, T., Suzuki, M. \& Hatano, K. (2002). Phylogenetic structure of the genera Flexibacter, Flexithrix, and Microscilla deduced from $16 \mathrm{~S}$ rRNA sequence analysis. J Gen Appl Microbiol 48, 155-165.

Oyaizu, H., Komagata, K., Amemura, A. \& Harada, T. (1982). A succinoglycan-decomposing bacterium Cytophaga arvensicola sp. nov. J Gen Appl Microbiol 28, 369-388.

Reichenbach, H. (1989). Genus Flexibacter Soriano 1945, 92, ${ }^{\mathrm{AL}}$ emend. In Bergey's Manual of Systematic Bacteriology, vol. 3, pp. 2061-2071. Edited by J. T. Staley, M. P. Bryant, N. Pfennig \& J. G. Holt. Baltimore: Williams \& Wilkins.

Reichenbach, H. (1992). The order Cytophagales. In The Prokaryotes, 2nd edn, vol. 4, pp. 3631-3675. Edited by A. Balows, H. G. Trüper, M. Dworkin, W. Harder \& K. H. Schleifer. New York: Springer.

Sangkhobol, V. \& Skerman, V. B. D. (1981). Chitinophaga, a new genus of chitinolytic myxobacteria. Int J Syst Bacteriol 31, 285-293.

Sly, L. I., Taghavi, M. \& Fegan, M. (1999). Phylogenetic position of Chitinophaga pinensis in the Flexibacter-Bacteroides-Cytophaga phylum. Int J Syst Bacteriol 49, 479-481.

Smibert, R. M. \& Krieg, N. R. (1994). Phenotypic characterization. In Methods for General and Molecular Bacteriology, pp. 607-654. Edited by P. Gerhardt, R. G. E. Murray, W. A. Wood \& N. R. Krieg. Washington, DC: American Society of Microbiology.

Takeuchi, M. \& Yokota, A. (1992). Proposals of Sphingobacterium faecium sp. nov., Sphingobacterium piscium sp. nov., Sphingobacterium heparinum comb. nov., Sphingobacterium thalpophilum comb. nov. and two genospecies of the genus Sphingobacterium and synonymy of Flavobacterium yabuuchiae. J Gen Appl Microbiol 38, $465-482$.

Thompson, J. D., Gibson, T. J., Plewniak, F., Jeanmougin, F. \& Higgins, D. G. (1997). The CLUSTAL_X windows interface: flexible strategies for multiple sequence alignment aided by quality analysis tools. Nucleic Acids Res 25, 4876-4882.

Xie, C.-H. \& Yokota, A. (2006). Reclassification of [Flavobacterium] ferrugineum as Terrimonas ferruginea gen. nov., comb. nov., and description of Terrimonas lutea sp. nov., isolated from soil. Int J Syst Evol Microbiol 56, 1117-1121.

Young, C.-C., Kämpfer, P., Shen, F.-T., Lai, W.-A. \& Arun, A. B. (2005). Chryseobacterium formosense sp. nov., isolated from the rhizosphere of Lactuca sativa L. (garden lettuce). Int J Syst Evol Microbiol 55, 423-426. 